\title{
The Social Networks and Engagements of Older Turkish Migrants in Germany
}

\author{
Ferhan Saniye Palaz \\ Istanbul University, Department of Sociology, Istanbul, TURKEY
}

Received: 14 March 2020 • Accepted: 28 May 2020 • Published Online: 20 July 2020

\begin{abstract}
During the 1960s, Germany received high numbers of Turkish labor migrants, and this first generation has currently reached to old age. This qualitative research aims to discuss the social networks and engagements of these older Turkish migrants who have aged in Germany. Academia has shown growing interest in the importance of social capital of older people in the form of their social networks, social support, and social participation. This study focuses on their daily social interactions in Germany. The findings reveal that participation in associations, social clubs, and neighborhood social groups enables them to re-establish new social roles in postretirement period and after their child-bearing years. Their small groups, which meet regularly, are valuable emotional support resources. Their relatively low human capital is argued to influence the homogeneity of their social networks, but not the variety of social engagements.
\end{abstract}

Keywords: aging, transnational aging, social capital, social engagement, social networks, older migrants.

\section{Introduction}

Aging and migration have been dominant factors in Europe's socio-demographic change since the 1950s and influenced several European countries' domestic political agenda, from macro-economic management to community relations (Ruspini, 2009; Warnes et al., 2004). For countries, which have imported a migrant labor force after World War II, older migrants constitute a growing population stratum (Ciobanu \& Hunter, 2017). Germany is known to have developed a highly organized labor migration system in Europe's post-war history and has concluded recruitment agreements with Turkey in 1961, as well as with many other countries between 1955 and 1973 (Castles \& Kosack, 1973).

According to official policies, "guest workers" were meant to be temporary. But even after suspending of the program in 1973, most didn't return, and additional flow of migration occurred for family reunification (Schierup, Hansen \& Castles, 2006). The exact number of Turkish guest workers, who have migrated to Germany between 1961 and 1973, is unknown (Yurdakul, 2009). According to Kaya (2007), many Turkish migrants in Germany have practically and symbolically have made both countries their social sphere. Portes, Guarnizo and Landolt (1999) characterize migrants' "dual life" as having homes in two countries, speaking two languages, and making a living through continuous regular contact across national borders. Currently, the Turkish immigrants and their children are the largest ethnic minority group in Germany (Barwick \& Beaman, 2019), and the first-generation of migrants have already retired or

(C) Authors. Terms and conditions of Creative Commons Attribution 4.0 International (CC BY 4.0) apply. Correspondence: Ferhan Saniye Palaz (PhD candidate), Istanbul University, Department of Sociology, Istanbul, TURKEY. E-mail: ferhanpalaz@gmail.com. 
approaching to their retirement age. Migrants are becoming a substantial part of Europe's older population (Ciobanu, Fokkema \& Nedelcu (2017). A majority of this population group in the Western Europe includes labor migrants who arrived before 1970s (Lanzieri, 2011).

The number of those, who return to their country of origin, is known to decrease with age (Bolzman et al., 2004). Even with a persistent intention to spend retirement in their country of birth, most stay in the country of immigration (Fokkema \& Naderi, 2013). According to Liversage and Mizrahi Mirdal (2017), the intention of first-generation Turkish adults in Denmark to return their home countries changes gradually with time based on economic status, healthcare needs, and where their children live. Older migrants, who migrated while young, maintain bridges between the two countries to link their two identities through their home designs, holiday traditions, traditional foods, and associations and clubs they attend (George \& Fitzgerald, 2012). First-generation migrants tend to stay emotionally attached to both their home and host countries (Phillipson et al., 2003 and Gardner, 2006; as cited in Buffel, 2017).

Overall, global migration has led to a new type of aging that takes place in a transnational social sphere (Castells, 1996; as cited in Heikkinen \& Lumme-Sandt, 2013). In transnational aging, multiple places simultaneously have value to older adults (Klok et al., 2017). Thus, considering different sorts of social networks rather than focusing solely on a local basis becomes increasingly important for academic debate (Ryan et al., 2008). According to Horn and Schweppe (2017), by cutting across many themes such as everyday practices, biographies, family relationships, social services, well-being, and social policy related to aging research, transnational aging offers us a broader approach to the existing theoretical paradigm. Warnes and Williams (2006: 12) stated that international migrants' aging to be "at the meeting-ground between two well-established academic and applied fields: migration studies and social gerontology."

This paper investigates the social networks and engagements of the first-generation older Turkish migrants, who have aged in Germany using qualitative research, focusing on their social space in the country of immigration as their geographical mobility between two countries tends to diminish with health problems and disabilities (Stuck et. al., 1999). In the light of Gray's (2009) study, social networks and engagements through formal organizations refer to clubs and faith-based organizations, and informal ties with friends and neighbors. Social capital theorist Putnam's (2000) ideal types macher and schmoozer are used. Macher refers to social networks and engagements, which are based on various cultural, political, and leisure activities/events like attending meetings in faith-based organizations / social clubs, volunteer work, giving speeches, and voting in neighborhood improvement associations and so on. Schmoozer also hints at an active social life, but is much less planned and more spontaneous, such as organizing dinners for friends at home, playing card games, passing free time with neighbors, and visiting family members. Putnam (2000) concludes that the one, who does any of the aforementioned activities, is more likely to do the rest. According to Nyqvist and Forsman (2015), the major strength of using social capital theory in aging research is its capacity to cut across different disciplines like public health, social policy, sociology, economics, and political science, and it is therefore applicable to a variety of disciplines. Interest has grown within academic debate on social capital's importance in old age (Poulsen et al., 2011).

Social networks function at different levels, namely: interpersonal, neighborhood, community, governmental, and institutional (Börsch-Supan et al., 2015). To avoid loneliness and isolation in old age, the most successful social network type results from long-term residence and active community involvement in organizations. Authors call these close relationships with local family, friends, and neighbors as "locally integrated support networks" (Wenger, Burgholt \& Scott, 2001; as cited in Gray, 2009). Several studies support the significance of involvement in formal organizations and community in old age (Liu \& Besser, 2003). 
Several studies have discussed and evidenced strong social networks and engagements' positive effect on health and well-being in old age. According to results of de Donder et al. (2012) study, attending cultural activities and being an association/club member contribute to higher levels of feeling safe in old age. Steffens et al. (2016) suggest that club membership in old age to is associated with higher levels of life quality and lower levels of early mortality. Moreover, according to studies conducted by Cruwys et al. (2013; 2014), having membership in more than one club helps to decrease the risk of depression. Warburton and McLaughlin (2005) suggest that older people's individual small gestures of volunteerism to be important to both communities and families. Increased social interaction and membership in different clubs reduce memory decline and vulnerability to dementia (Ertel, Glynour \& Berkman, 2008; Fratiglioni, Paillard-Borg \& Winblad, 2004; as cited in Gleibs et al., 2011).

According to Ysseldyk, Haslam and Haslam (2013), social networks provide a basis for maintaining social identity among older adults in the context of major life transitions, such as episodes of hardships resulting from illness or injury (Haslam et al., 2008), significant life events like entering a nursing home (Knight et al., 2010), the gradual process of aging itself (Aldwin et al., 2007), and perhaps even being reminded of one's own mortality (Sani, Herrera \& Bowe, 2009). For migrants, aging adds unique challenges to these life transitions, such as feeling even more homesick even more after retirement and confronting exclusion/social disadvantages (Patzelt, 2017). Thus, social networks and engagements become even more significant for aging migrants.

\section{Methods and research contextualization}

This research aims to understanding the older Turkish migrants' social networks and engagements by evaluating their daily social interactions based on semi-structured interviews. The interviews give insight into: (1) what urban and public spaces they use to socialize? (2) who they would prefer to socialize with and also how frequently?, and (3) how accessible are their current homes and how it affects their social networks and engagements?. The interviews have been carried out in 2016, five in Berlin, seven in Cologne, and six in Frankfurt. I intended to include a more diverse group after the qualitative research, which I had conducted mostly in mosque-related associations and participants' houses in the Netherlands in 2015 (Palaz \& Adıgüzel, 2016). However, I could only partly achieve this because most potential participants did not agree to be interviewed by me. At the end, I conducted eight interviews in mosque-related associations, two in secular/political associations, two in Turkish coffee houses, two in German local coffee shops (bäckerei), and four in their homes.

This study uses the phenomenological research design. The participant requirements, which have been determined by using the social science literature, include: an age group over 60 years, good health condition, and a migrant status at a young age. The problem-centered interview has been chosen as the data collection technique. Audio recordings of the collected data has been transcribed for systematic interpretation and descriptive analysis. After determining the themes, systematic analysis has been performed by defining the correlation between themes and transcripts (Kümbetoğlu, 2012; Mayring, 2011). Comments have been made according to the relevant literature on sociology after the data analysis.

All interviews have been conducted individually. Respondents have been recruited using snowball sampling. I have spent more time in these public and urban spaces than the duration of the interviews. The method, which I have used to achieve a relative high diversity, is to ask potential participants whether they are members of social club/association and if I could visit that place with them. I have managed to visit a secular/political association and Turkish coffee house this way. I have also asked participants if they know any first-generation older Turkish adults who would accept being interviewed by me. 
My interviewees vary in terms of religious, political, cultural, and ethnic backgrounds. The youngest participant in the study group is 63 , while the oldest one is 91 . All my participants have children, and many have grandchildren; fourteen participants are married and the rest are widowed. Some live in the same household/building with their descendants, but most live in different parts of the city.

As a native Turkish speaker, I have conducted all interviews in Turkish. As a consequence of different early life stage experiences, male participants have tended to speak German better. This was mostly related to their position in the work market. The gainfully employed female participants state Turkish to be the main/only language needed at work, so they have not learned German properly. I reference my informants' quotes by putting additional information in brackets, if necessary, to provide a clearer picture of the interview:

"I go to a sports center with one of them [one of her neighbors]."

Most participants, in this study, have graduated from elementary school. One is a teacher (University degree), one has a two-year college degree, and two are high school graduates. One female participant is currently learning to read and write in Turkish. Aside from the teacher and two women who have never had paid work, they all have worked as laborers. Two participants have started their own business (one market and one restaurant owner) after working for a time as laborers.

Their limitations with German language skills presented a challenge in their formal paperwork processes. Therefore, they have received assistance from either their children or Turkish friends. Seven are in poor health and mention not being satisfied with their general health. Still, all of my participants are healthy enough tocarry out their activities of daily living and go outdoors withour getting any kind of help or support. The majority have experienced economic difficulties after retirement.

My participants have given different examples of their social networks and engagements. For some, playing card games and baking bread with friends are valued and stable social engagements. For others, volunteering in an association or taking classes on a religious/cultural topic is the main social engagements. Consequently, all participants mention about having some sort of social engagement, mostly as schmoozers rather than machers, as I will evaluate below.

The places that I have visited differed from one another in regards to the community that they build. Mosque-related associations have a faith-based community. Turkish coffee house has its own regulars. The secular/political association has a more ideological sense of belonging. Meanwhile, the bäckerei offers no shared identity or sense of community. Excluding the bäckerei, one common factor is that these places evoke a strong sense of community and facilitate a place to socialize and organize different activities. Mosquerelated and secular/political associations provide opportunities for volunteer activities, reading clubs, recreational activities, group trips, picnic organizations, charity organizations, board games, shared TV rooms for watching a soccer match together and, even a small stage for traditional feasts. Mosque-related and secular/political associations offer a social environment both for schmoozers and machers. In the volunteer associations, firstgeneration members have a significant contribution in building both the physical and social environments of these places. 


\section{Social networks and engagement}

Two research questions of this study are which urban and public spaces they use to socialize and who they would prefer to socialize with and also how frequently. My participants meet friends at associations and clubs, take walks with neighbors, work voluntarily, attend educational courses and sport clubs. They also visit Turkey to spend their vacations at their hometowns and other cities and to celebrate religious holidays with their family members who live in Turkey. These activities creates the transnational context of their aging experience. Economic status has a crucial role in both their daily and transnational mobility. Some of them said they can't afford to visit Turkey as often as they want.

One of the questions of this research is about how accessible their current homes are and how it affects their social networks and engagements. In old age, homes and neighborhoods with easy access have a key role in social life. A majority of my participants lives in privately rented flats and they have been living in these houses for the most of their lives. Even though most of them stated their current homes to have convenient accessibility with an elevator or being a first-floor apartment, three experience challanges. They commonly stated to currently not struggle accessing public and urban spaces, but for some of them, this will become a challange in the future. A 74-year-old male participant, who has been interviewed at a mosquerelated association, highlights another factor to the picture - the economic burden of moving to a better-equipped house.

Due to their transnational aging experiences, my informants have developed unique practices for dealing with health issues. Some enjoy the social support embedded in both local and transnational social networks. A 75-year-old male participant, who has been interviewed, in a mosque-related association says:

"I have no family here... I had an operation on my knee in Turkey because I trusted the doctors there more. I came back here after the surgery... I can walk now using these [crutches], but I can't put on my socks. I have a German neighbor. He has been coming to my home every morning since the operation to [assist me to] put my socks on."

He also voluntarily helps other older Turkish migrants with their bureaucratic paperwork. His experience shows clearly the importance of maintaining social roles for elders' well-being during retirement:

"I go to the same bäckerei every day to help the older Turkish people with their retirement paper work. I have started doing this because I have experience with this kind of documentation. I have started one of the first Turkish associations in Cologne... People need to help for this kind of documentation. I feel useful because I don't have a family here."

Family responsibilities are also an important dimension in maintaining former social roles in the old age. According to Warburton and McLaughlin (2005), several ways exist in which older people contribute to their communities and families as informal volunteers. An 81year-old male participant, who has been interviewed in a Turkish coffee house, supports his daughters' work-life as a continuation of his professional identity and his role as a father:

"I have worked as a cook here. I spend my days here [Turkish coffee house]. I also help my daughters' restaurant. I do not cook but I organize the warehouse... After retirement you need to keep yourself busy to stay healthy."

Some participants maintain their former social roles and they have also gotten new ones. A 67-year-old female participant, who has been interviewed, supports her daughter at home and she attends an educational class. Her experience also gives a deeper perception of the importance of having different social networks for well-being: 
"I live with my daughter and her son. My daughter is divorced and she has started torun a lunch counter at the subway. I clean the house and cook. I also take her lunch every day. I make this house a home for them... I spend my leisure time with my neighbors. We meet every day... I have been going to school to learn reading and writing in Turkish for the last four years now."

An important part of my participants' social networks and engagements was their participation in these associations and clubs. These places were valuable social support resources for them. They support eachother with giving advice on the different challanges of transnational aging experience. Their interactions in these associations is quite informal, and people know each other for a long time. A 76-year-old male participant, who has been interviewed in a mosque-related association, gives a detailed example of how important these associations are in their daily social life:

"We have religious lessons three times a week, I attend them regularly. We live here as a community, that's how we can endure our elderly years in exile [he uses the Turkish word gurbet, which means living in a foreign land and feeling homesick].”

My informants chose the associations and clubs that they attend to based on the community they want to interact with. Most take part in a certain community, with just a few who attend more than one. As a consequence of their different preferences, the variety of social networks differs greatly from one another. Most participants only socialize with people who share a relatively similar identity, while others socialize with people from different ethnic, religious, cultural, and political backgrounds. A 70-year-old male participant, who has been interviewed in a mosque-related association states that "I go to different Turkish mosques to meet friends and drink a cup of tea, but to pray I always go to an Arabic mosque where is also near here."

Some of them spend their leisure time with their friends in associations and return home for lunch or coffee because of economic difficulties. While some go to the associations to socialize as schmoozers, others actively participate in organizing the association as machers. According to Palmberger's study (2017) on older first-generation, the Turkish migrants living in Vienne and who access to cultural, political, and religious volunteer associations, feel socially well-embedded.

Older migrants, with resources embedded in wider social networks are affected by the extent they integrate with the wider community; and when lacking cultural capital, they rely on their own communities and families for specific support (Ruspini, 2009). The only welleducated participant among my informants is a 72-year-old man, who has been a teacher since years; and I have interviewed him in a secular/political association. He has various social networks, which is not common in my other research participants, and he has different social engagements:

"I have started going to the mosque after my retirement ....... I meet friends at the shopping mall. We drink coffee. I come here [secular/political association] a couple times a week. I don't share the same political tendencies with people here, but I enjoy their company... I am also a member of a Turkish-German health association. We organize seminars to raise awareness about diseases such as diabetes, strokes, and dementia... I am a member of the parents' association. I am not as active as I used to be, but sometimes I attend their meetings." 
As previously mentioned, most informants have social networks and engagements typical of schmoozers instead of machers. While only four have official memberships in clubs/associations, six volunteer at associations' charity events. They bake Turkish pizza, serve food, clean the place, or organize certain parts of the event. A 67-year-old female participant, who has been interviewed at her home, actively volunteers at different mosquerelated associations without having any official membership. She highlights associations not as somewhere with close social ties, but as a place to visit for philanthropic reasons. Her experiences with her neighbors also vividly describe the importance of having social networks outside the family. She highlights that they have grown old together as neighbors and have become like a family, and they do not have close relationships with their relatives in Turkey anymore. According to Buffel (2017), understanding older migrants' aging experience requires attention to how they re-create a sense of home. My interviewees stress strong social ties and neighborly support as another dimension of their social networks and engagements.

\section{Discussion}

Most of my participants have a strong sense of community based on these associations and clubs, and they have a strong social network and social support mechanism. These all work to their advantage in overcoming the challenges of transnational aging experience. These actions reflect the sense of community, as analyzed by Liu and Besser (2003) in their study on older adults' social capital with a focus on their community involvement. In addition to attending associations, several participants also join a social club or neighborhood social group. According to Patzelt's (2017) study on older migrants, this is a valuable approach for dealing with grief after losing a spouse and to remain isolate at home. All these social interactions also help them re-establishing new social roles after retirement and child-bearing years. Their small groups with neighbors and "coffee friends" are valuable sources of emotional support. The small groups meet regularly and provide the participants with support/care (Wuthnow, 1994; as cited in Putnam, 2000).

Higher education and employment status are generally associated with higher levels of social capital in old age (Cramm \& Nieboer, 2015). However, this is only partly true for participants of this study. Their relatively low human capital can be said to be related to the homogeneity of their social networks, but not to the variety of social engagements. Moreover, according to Collom's study (2008) on older adults' volunteerism, they prefer interacting with younger generations, and this socialization serves as a bridge between generations and enhances social integration in old age. This is not the case with participants of this study. Their social network and engagements mostly consisted of their peers. This can result from being a firstgeneration migrant. They may prefer spending their leisure time with those who share similar life paths. More studies with different migrant generations are needed to develop our understanding on this issue. Additionally, more studies are needed to understand the role of NGOs, which have the potential for more inclusive societies (Şentürk, 2014).

People's attachment to residential environment increases with age due to mobility limitations (Gilleard et al., 2007). Consequently, they tend to spend more time at home. Thus, the physical and social environment has an essential role in old age. Environmental inadequacies can limit older adults' full social participation, especially when combined with increased vulnerability to potentially disabling physical/cognitive conditions (Scharlach \& Lehning, 2013). Crisis-proof policies lessening older adults' economic burden of moving to better-equipped homes will gain more importance for policy makers through adequate academic research, which is particularly needed on this issue. 
Compared to non-migrant peers, older migrants in Europe are known to tend to have worse self-rated health and unassisted functioning, as well as higher depression rates and chronic conditions (Aichberger et al., 2010; Lanari \& Bussini, 2012). Considering the significant correlations of general health, well-being, and strong social capital into consideration, studying older migrants' social networks and engagements becomes especially important. From the perspective promoting health, encouraging volunteerism in old age as a mean of tackling these issues may be a vital step (Hirschfelder \& Reilly, 2007; as cited in Theurer \& Wister, 2010). Public policy and academic debate should also take dimensions into account that go beyond older people' health and material conditions, such as access to public facilities, services, and social relations (Myck et al., 2015). More research is needed to understand the most effective ways to promote health through social capital among older people who've migrated.

While research on young migrants in Europe is widespread, older migrants are still an understudied population (Hunkler et al., 2015). According to Dwyer and Papadimitriou (2006), European Union (EU) member states' policy agendas don't prioritize improving older international migrants' rights. Also, a lack of quantitative data exists on older migrant populations, with no projections present for most of EU member states (Rallu, 2017), even though they can provide the necessary information to estimate future social and health service needs (Rees et al., 2013). The current reluctance to making crisis-proof policies related to older migrants in EU member states causes a dilemma in the EU's aim of "inclusive, innovative, and reflective societies". In addition to projections, older migrants and their families should be included in national samples of large surveys as a matter of standard practice (Schans \& Komter 2010). More academic research is needed to provide this sort of qualitative data.

The second-generation of Turkish migrants are also generally an important population group for aging studies. In Germany's case, Turkish descendants constitute the largest immigrantorigin group (Barwick \& Beaman, 2019). Even though debate is found whether older migrants often prefer support from their children to formal support (Ciobanu, Fokkema \& Nedelcu, 2017; de Valk \& Schans 2008), we cannot assume older migrants will be automatically supported by their adult children (Schans \& Komter, 2010). Apart from healthcare, descendants' potential for financially abusing older migrants is a highly important research subject (Park \& Kim, 2013). More research on intergenerational relationships is needed. In addition to being aware of different migrant generations, Warnes et al. (2004) highlight the significance of different migration histories for future studies, making a distinction for people who migrated younger and aged in a host country with those who migrated after retirement. These background trajectories should be considered while studying with older migrants. Another important dimension that need further investigation is the comparative studies between different countries of migration.

Furthermore, one limitation of this study is that only cross-sectional data has been collected. As a qualitative research, it does not represent the majority. Another limitation is the gender division of my participants. This study includes more male participants (i.e. 13 men) and less female participants (i.e. 5 women).

In sociological studies, especially in Turkey, the role of family in social relations has become clear. This study contributes to the recent social science literature in Turkey by debating the importance of intergenerational relations after migrating from Turkey to a foreign country. Also, hometown associations resulting from both internal and international migrations in Turkey are an important research topic in the Turkish sociological studies. This paper contributes to the current literature by adding a perspective on migrants in Europe and who have a Turkish backgrounded. Lastly, most aging studies in Turkey primarily focus on health and economic wellbeing of older adults. This study brings their social interactions to the forefront. 


\section{Acknowledgements}

This research did not receive any specific grant from funding agencies in the public commercial, or not-for-profit sectors.

The author declares no competing interests.

The author would like to thank the anonymous reviewers, and wishes also to thank those who shared their stories with her and who invited her into their homes.

\section{References}

Adıgüzel, Y. (2011). Diyasporadaki kimlik algılamalarına göç tipinin etkisi: Almanya ve İngiltere Türk toplumlarının karşılaştırılması [Comparison of cultural identity perception of Turkey originateds in Germany and England]. İstanbul Üniversitesi Sosyoloji Dergisi, 3(20), 97-119. Retrieved from https://dergipark.org.tr/tr/pub/iusosyoloji/issue/515/4703.

Aichberger, M. C., Schouler-Ocak, M., Mundt, A., Busch, M. A., Nickels, E., Heimann, H. M., Ströhle, A., Reischies, F. M., Heinz, A., \& Rapp, M. A. (2010). Depression in middle-aged and older first generation migrants in Europe: Results from the Survey of Health, Ageing and Retirement in Europe (SHARE). European Psychiatry 25, 468-475. https://doi. org/10. 1016/j.eurpsy. 2009. 11.009

Aldwin, C. M., Park, C. L., \& Spiro, A. III (2007). Handbook of health psychology and aging. New York: Guilford Press.

Barwick, C., \& Beaman, J. (2019). Living for the neighbourhood: Marginalization and belonging for the second-generation in Berlin and Paris. Comparative Migration Studies, 7(1), 1-17. https://doi.org/10.1186/s40878-018-0105-3

Bolzman, C., Raffaelle, P., Vial, M., \& Fibbi, R. (2004). Older labour migrants' well-being in Europe: The case of Switzerland. Ageing and Society, 24(3), 411-429.

https://doi.org/10.1017/So144686X03001557

Börsch-Supan, A., Kneip, T., Litwin, H., Myck, M., \& Weber, G. (2015). SHARE: A European policy device for inclusive ageing societies. In A. Börsch-Supan, T. Kneip, H. Litwin et al. (Eds.), Ageing in Europe- Supporting Policies for an Inclusive Society (pp. 1-22). Berlin, Boston: De Gruyter. https://doi.org/10.6103/SHARE.w5.700

Buffel, T. (2017). Ageing migrants and the creation of home: Mobility and the maintenance of transnational ties. Population, Space and Place, 23, 1-13. https://doi. org/10. 1002/psp.1994

Castells, M. (1996). The rise of the network society. Oxford: Blackwell.

Castles, S., \& Kosack, G. (1973). Immigrant workers and class structure in Western Europe. London, New York, Toronto: Oxford University Press.

Ciobanu, R. O., Fokkema, T., \& Nedelcu, M. (2017). Ageing as a migrant: Vulnerabilities, agency, and policy implications. Journal of Ethnic and Migration Studies, 43(2), 164-181. https://doi.org/10. 1080/1369183X.2016.1238903

Ciobanu, R. O., \& Hunter, A. (2017). Older migrants and (im)mobilities of ageing: An introduction. Population, Space and Place, 23, 1-10. https://doi.org/10.1002/psp.2075

Collom, E. (2008). Engagement of the elderly in time banking: The potential for social capital generation in an aging society. Journal of Aging and Social Policy, 20(4), 414-436. https://doi.org/10.1080/08959420802186282

Cramm, J. M., \& Nieboer, A. P. (2015). Building social capital may protect against loss of well-being among 
older people. In F. Nyqvist \& A. K. Forsman (Eds.), Social capital as a health resource in later life: The relevant of context (pp. 145-154). Dordrecht, Heidelberg, New York, London: Springer.

Cramm, J. M., van Dijk, H. M., \& Nieboer, A. P. (2012). The importance of neighborhood social cohesion and social capital for the well being of older adults in the community. The Gerontologist, 53(1), 142-150. http://doi.org/10.1093/geront/gnso52

Cruwys, T., Dingle, G. A., Haslam, C., Alexander Haslam, S., Jetten, J., \& Morton, T. A. (2013). Social group memberships protect against future depression, alleviate depression symptoms and prevent depression relapse. Soc Sci Med, 98, 179-186. https://doi. org/10.1016/j.socscimed.2013.09. $\underline{013}$

Cruwys, T., Alexander Haslam, S., Dingle, G. A., Jetten, J., Hornsey, M. J., Desdemona Chong, E. M., \& Oei, T. P.S. (2014). Feeling connected again: Interventions that increase social identification reduce depression symptoms in community and clinical settings. $J$ Affect Disord, 159, 139-146. https://doi.org/10.1016/j. jad.2014.02.019

de Donder, L., De Witte, N., Buffel, T., Dury, S., \& Verte, D. (2012). Social capital and feelings of unsafety in later life: A study on the influence of social networks, place attachment, and civic participation on perceived safety in Belgium. Research on Aging, 34(4), 425-448. https://doi. org $/ 10.1177 / 0164027511433879$

de Valk, H. A. G., \& Schans, D. (2008). 'They ought to do this for their parents': Perceptions of filial obligations among immigrant and Dutch older people. Ageing and Society, 49-66. https://doi.org/10.1017/S0144686X07006307

Dwyer, P., \& Papadimitriou, D. (2006). The social security rights of older international migrants in the European union. Journal of Ethnic and Migration Studies, 32(8), 1301-1319. https://doi.org/10.1080/13691830600927773

EN Horizon 2020 Work Programme 2018-2020 (2019). Europe in a changing World - Inclusive, innovative and reflective societies. Retrieved from https://ec.europa.eu/research/participants/data/ref/h2020/wp/2018-2020/main/h2020wp1820-societies en.pdf

Ertel, K. A., Glymour, M. M., \& Berkman, L. F. (2008). Effects of social integration on preserving memory function in a nationally representative US elderly population. American Journal of Public Health, 98, 1215-1220. https://doi.org/10.2105/AJPH.2007.113654

Fratiglioni, L., Paillard-Borg, S., \& Winblad, B. (2004). An active and socially integrated lifestyle in late life might protect against dementia. The Lancet Neurology, 3, 343-353. https://doi.org/10.1016/S1474-4422(04)00767-7

Fokkema, T., \& Naderi, R. (2013). Differences in late-life loneliness: A comparison between Turkish and native-born older adults in Germany. Eur $J$ Ageing, 10, 289-300. http://doi.org/10.1007/s10433-013-0267-7

Gardner, K. (2006). Narrative, age and migration: Life history and the life course amongst Bengali elders in London. Oxford: Berg.

George, M. \& Fitzgerald, R. (2012). Forty years in Aotearoa New Zealand: White identity, home and later life in an adopted country. Ageing \& Society, 32, 239-260. https://doi.org/10.1017/S0144686X11000249

Gilleard, C., Hyde, M., \& Higgs, P. (2007). The impact of age, place, aging in place, and attachment to place on the well-being of the over 50s in England. Research on Aging, 29, 590-605. https://doi.org/10.1177/0164027507305730

Gleibs, I. H., Haslam, C., Alexander Haslam, S., \& Jones, J. M. (2011). Water clubs in residential care: Is it the water or the club that enhances health and well-being? Psychology \& Health, 26(10), 13611377. https://doi.org/10.1080/08870446.2010.529140 
Gray, A. (2009). The social capital of older people. Ageing \& Society, 29, 5-31. https://doi.org/10.1017/S0144686X08007617

Haslam, C., Holme, A., Haslam, S. A., Iyer, A., Jetten, J., \& Williams, W. H. (2008). Maintaining group memberships: Social identity continuity predicts well-being after stroke. Neuropsychological Rehabilitation, 18, 671-691. https://doi.org/1080/09602010701643449

Heikkinen, S. J., \& Lumme-Sandt, K. (2013). Transnational connections of later-life migrants. Journal of Aging Studies, 27, 198-206. http://doi.org/10.1016/j.jaging.2013.02.002

Hirschfelder, A. S., \& Reilly, S. L. (2007). Rx: Volunteer: A prescription for healthy aging. In S. G. Post (Ed.), Altruism and health (pp. 116-40). New York: Oxford University Press. https://doi.org/10.1093/acprof:0so/9780195182910.003.0010

Horn, V., \& Schweppe, C. (2017). Transnational aging: Toward a transnational perspective in old age research. Eur J Aging, 14, 335-339. https://doi.org/10.1007/s10433-017-0446-z

Hunkler, C., Kneip, T., Sand, G., \& Schuth, M. (2015). Growing old abroad: Social and material deprivation among first- and second- generation migrants in Europe. In A. Börsch-Supan, T. Kneip, H. Litwin et al. (Eds.), Ageing in Europe - Supporting policies for an inclusive society (pp. 199208). Berlin, Boston: De Gruyter.

Kaya, A. (2007). German-Turkish transnational space: A separate space of their own. German Studies Review, 3o(3), 483-502. Retrieved from http://www.jstor.org/stable/27668369.

Knight, C., Haslam, S. A., \& Haslam, C. (2010). In home or at home? Evidence that collective decision making enhances older adults' social identification, well-being and use of communal space when moving to a new care facility. Ageing and Society, 30, 1393-1418. https://doi.org/10.1017/S0144686X10000656

Klok, J., van Tilburg, T. G., Suanet, B., \& Fokkema, T. (2017). Transnational aging among older Turkish and Moroccan migrants in the Netherlands: Determinants of transnational behavior and transnational belonging. Transnational Social Review, 7(1), 25-40. https://doi.org/10.1080/21931674.2016.1277656

Kümbetoğlu, B. (2012). Sosyolojide ve antropolojide niteliksel yöntem ve ara ştırma [Qualitative method and research in sociology and anthropology]. İstanbul: Bağlam.

Lanari, D. \& Bussini, O. (2012). International migration and health inequalities in later life. Ageing \& Society, 32, 935-962. https://doi.org/10.1017/S0144686X11000730

Lanzieri, G. (2011). Fewer, older and multicultural? Projections of the EU populations by foreign/national background. Luxemburg: Eurostat. https://doi.org/10. 2785/17529

Liu, A. Q., \& Besser, T. (2003). Social capital and participation in community improvement activities by elderly residents in small towns and rural communities. Rural Sociology, 68(3), 343-365. https://doi.org/10.1111/j.1549-0831.2003.tbo0141.X

Liversage, A., \& Mirdal, G. M. (2017). Growing old in exile - A longitudinal study of migrant women from Turkey. Journal of Ethnic and Migration Studies, 43(2), 287-302. https://doi.org/10.1080/1369183X.2016.1238910

Mayring, P. (2011). Nitel sosyal araştırmaya giriş (A. Güçüş \& M. S. Durgun, Çev.) [Introduction to qualitative social research]. Ankara: Bilgesu.

Moya, J. C. (2005). Immigrant and associations: A global and historical perspective. Journal of Ethnic and Migration Studies, 31(5), 833-864. https://doi.org/10.1080/13691830500178147

Munford, L. A., Sidaway, M., Blakemore, A., Sutton, M., \& Bower, P. (2017). Associations of participation in community assets with health-related quality of life and healthcare usage: a cross-sectional study of older people in the community. BMJ Open, 7, 1-9. http://doi.org/10.1136/bmjopen2016-012374 
F. S. Palaz - The Social Networks and Engagements of Older Turkish Migrants in Germany

Myck, M., Najsztub, M., \& Oczkowska, M. (2015). Measuring social deprivation and social exclusion. In A. Börsch-Supan, T. Kneip, H. Litwin et al. (Eds.), Ageing in Europe - Supporting policies for an inclusive society (pp. 67-77). Berlin, Boston: De Gruyter.

Nyqvist, F., \& Forsman, A. K. (2015). Healthy ageing: Focus on social capital. In F. Nyqvist \& A. K. Forsman (Eds.), Social capital as a health resource in later life: The relevant of context (pp. 1-11). Dordrecht: Springer.

Palaz, F. S., \& Adıgüzel, Y. (2016). Active aging experiences of Turkish immigrants in Netherlands. Turkish Journal of Sociology, 36, 37-45. http://doi.org10.16917/iusosyoloji.291223

Palmberger, M. (2017). Social ties and embeddedness in old age: older Turkish labour migrants in Vienne. Journal of Ethnic and Migration Studies, 43(2), 235-249. http://doi.org/10.1080/1369183X.2016.1238907

Park, H. J., \& Kim, C. G. (2013). Ageing in an inconvenient paradise: The immigrant experiences of older Korean people in New Zealand. Australian Journal on Ageing, 32(3), 158-162. https://doi.org/10.1111/j.1741-6612.2012.00642.X

Patzelt, A. (2017). 'A totally new world has been opening up for me' - Experiences of older German migrants who are actively involved in the German-speaking community in Ottawa, Canada. Journal of Ethnic and Migration Studies, 43(2), 218-234. https://doi.org/10.1080/1369183X.2016.1238906

Phillipson, C., Ahmed, N., \& Latimer, J. (2003). Women in transition. A study of the experiences of Bangladeshi women living in tower hamlets. Bristol: Policy Press.

Polacsek, M., \& Angus, J. (2016). Making themselves at home: Support needs of older Germans in Australia. Australian Journal on Ageing, 35(3), E1-E5. https://doi.org/10. 1111/ajag.12263

Portes, A., Guarnizo, L. E., \& Landolt, P. (1999). The study of transnationalism: pitfalls and promise of an emergent research field, Ethnic and Racial Studies, 22(2), 217-237. https://doi.org/10.1080/014198799329468

Poulsen, T., Christensen, U., \& Lund, R. (2011). Measuring aspects of social capital in a gerontological perspective. Eur J Ageing, 8, 221-232. https://doi.org/10.1007/s10433-011-0205-5

Putnam, R. (2000). Bowling alone. New York: Simon \& Schuster.

Rallu, J. L. (2017). Projections of older immigrants in France, 2008-2028. Populations, Space and Place, 23, 1-14. https://doi.org/10.1002/psp.2012

Rees, P., Zuo, C., Wohland, P., Jagger, C., Norman, P., Boden, P., \& Jasinska, M. (2013). The implications of ageing and migration for the future population, health, labour force and households of Northern England. Applied Spatial Analysis \& Policy, 6, 93-122. https://doi.org/10.1007/s12061-013-9086-7

Ruspini, P. (2009). Elderly Migrants in Europe: An overview of trends, policies and practices. Suiça: University of Lugano (USI).

Ryan, L., Sales, R., Tilki, M., \& Siara, B. (2008). Social networks, social support and social capital: The experiences of recent Polish migrants in London. Sociology, 42(4), 672-690. https://doi.org/10.1177/0038038508091622

Sani, F., Herrera, M., \& Bowe, M. (2009). Perceived collective continuity and in-group identification as defense against death awareness. Journal of Experimental Social Psychology, 45(1), 242-245. https://doi.org/10.016/j. jesp.2008.07.019

Schans, D., \& Komter, A. (2010). Ethnic differences in intergenerational solidarity in the Netherlands. Journal of Aging Studies, 24, 194-203. https://doi.org/10.1016/j. jaging.2008.10.007

Scharlach, A. E., \& Lehning, A. J. (2013). Ageing-friendly communities and social inclusion in the United States of America. Ageing \& Society, 33, 110136. https://doi.org/10.1017/So144686X12000578 
Schierup, C., Hansen, P., \& Castles, S. (2006). Migration, citizenship, and the European welfare state: A European dilemma. Oxford University Press. https://dooi.org/10.1136/bmjopen-2015-010164

Steffens, N. K., Cruwys, T., Haslam, C., Jetten, J., \& Haslam, S. A. (2016). Social group memberships in retirement are associated with reduced risk of premature death: evidence from a longitudinal cohort study. BMJ Open, 6, 1-9. https://doi.org/10.1136/bmjopen-2015-010164

Stuck, A., Walthert, J., Nikolaus, T., Büla, C., Hohmann, C., \& Beck, J. (1999). Risk factors for functional status decline in community-living elderly people: a systematic literature review. Social Science and Medicine, 48, 445-469. https://doi.org/10.1016/s0277-9536(98)00370-0

Şentürk, M. (2015). Türkiye'de kamunun ve stk'ların sosyal yardım uygulamaları: Yeni eğilimler ve ihtiyaçlar [Social assistance applications of the public and NGOs in Turkey: Recent trends and needs]. İstanbul Üniversitesi Sosyoloji Dergisi, 3(28), 0-307. Retrieved from https://dergipark.org.tr/tr/pub/iusosyoloji/issue/560/5549

Theurer, K., \& Wister, A. (2010). Altruistic behaviour and social capital as predictors of well-being among older Canadians. Ageing \& Sociology, 30, 157-181.

https://doiorg/10.1017/S0144686X09008848

Uslaner, E. M., \& Conley, R. S. (2003). Civic engagement and particularized trust - The ties that bind people to their ethnic communities. American Politics Research, 31(4), 331-360. https://doi.org/10.1177/1532673X03031004001

van der Meer, T. (2016). Neither bridging nor bonding a test of socialization effects by ethnically diverse voluntary associations on participants' inter-ethnic tolerance, inter-ethnic trust and intraethnic belonging. Social Science Research, 55, 63-74. https://doi.org/10 1016/j.ssresearch.2015.09.005

Warburton, J., \& McLaughlin, D. (2005). 'Lots of little kindnesses': Valuing the role of older Australians as informal volunteers in the community. Ageing \& Society, 25, 715-730. https://doi.org/10.1017/S0144686X05003648

Ysseldyk, R., Haslam, S. A., \& Haslam, C. (2013). Abide with me: Religious group identification among older adults promotes health and well-being by maintaining multiple group memberships. Aging \& Mental Health, 17(7), 869-879. https://doi.org/10.1080/13607863.2013.799120

Yurdakul, G. (2009). From guest workers into Muslims: The transformation of Turkish immigrant associations in Germany. UK: Cambridge Scholars Publishing.

Warnes, A. M., \& Williams, A. (2006). Older migrants in Europe: A new focus for migration studies, Journal of Ethnic and Migration Studies, 32(8), 1257-1281, https://doi.org/10.1080/13691830600927617

Warnes, A. M., Friedrich, K., Kellaher, L., \& Torres, S. (2004). The diversity and welfare of older migrants in Europe. Ageing and Society, 24(3), 307-326. https://doi.org/10.1017/So144686X04002296

Wenger, G. C., Burholt, V., \& Scott, A. (2001). The ageing process: The Bangor longitudinal study of ageing 1979-1999. Centre for Social Policy Research and Development, Institute of Medical and Social Care, University of Wales, Bangor, Gwynedd. 
F. S. Palaz - The Social Networks and Engagements of Older Turkish Migrants in Germany

C O A $\mathbf{s}$ 